\title{
MIGRAÇÃO NUM MUNDO DO TRABALHO EM TRANSFORMAÇÃO
}

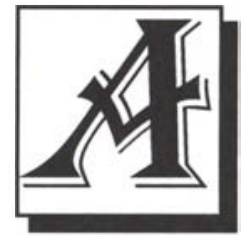

expressão "migração laboral” costuma ser utilizada, mormente em outros países, para designar migrações condicionadas única ou preferencialmente pela busca ou exercício do trabalho. Uma espécie de "verbete" ou palavra-chave utilizada para classificar ou criar tipologias e, assim, distinguir determinadas formas de migração de outras, no universo dos deslocamentos humanos. No entanto, tal expressão suscita questionamentos, justamente porque na sociedade moderna e na economia de mercado, a realidade do trabalho não seria simplesmente uma forma de catalogação ao lado de outras, sem mais. $\mathrm{Na}$ medida em que o trabalho seria constitutivo do fato mesmo da migração numa sociedade capitalista, não se poderia falar de migração sem referir-se à mobilidade no mundo do trabalho. Na verdade, a migração seria uma realidade própria e específica da sociedade capitalista, porque ela seria um dos fatores principais na produção da força-de-trabalho, enquanto uma mercadoria ímpar na formação do capitalismo, ou seja, aquela que propriamente realiza a criação de valor, motor do processo de acumulação capitalista.

Nessa perspectiva, entende-se porque vários fenômenos de deslocamentos humanos não poderiam ser encarados como migração, por não serem produzidos pela dinâmica própria do capitalismo no atual estágio de desenvolvimento, tais como a transumância, o nomadismo ou mesmo o tráfico negreiro. No entanto, no momento em que o capitalismo passa por grandes transformações, e o mundo do trabalho se reestrutura sob novas formas, outros fenômenos de "migração" surgem desafiando a concepção que alia tão estreitamente migração, mobilidade e trabalho. Trata-se do deslocamento de trecheiros, refugiados, idosos buscando tratamento de saúde, etc.

É numa época em que o mundo do trabalho passa por enormes transformações, no seio do capitalismo mundializado, que a Travessia propõe o tema da migração laboral. No terreno da migração interna traz a colaboração de José Gilberto, Wirley Jorge e José Gebara, sobre a reconstituição dos trabalhadores rurais nos assentamentos de Reforma Agrária; de Marilda Menezes, sobre o recrutamento de trabalhadores rurais temporários migrantes no corte da cana em Pernambuco; de Adélia Branco e Samira Vainsencher, sobre mulheres migrantes do sequeiro nordestino trabalhando na fruticultura irrigada do Médio São Francisco. No terreno das migrações internacionais tem as colaborações de Soraya Fleischer, sobre emigrantes brasileiras trabalhando no ramo da faxina (houseclean business) em Boston, nos Estados Unidos; de Lúcia Yamamoto, sobre a migração feminina internacional para o Japão e sua inserção laboral; de Soraia Vidal, sobre migração para o Canadá e as políticas de controle do governo canadense.

Apesar de se falar tanto em globalização para caracterizar o mundo contemporâneo, ainda vivemos numa sociedade capitalista. $O$ trabalho, assim, com todas as transformações pelas quais vem passando, ainda é um fator essencial na formação dessa sociedade, produzindo e condicionando os deslocamentos de população, bem como o cotidiano de todos os migrantes envolvidos nesse processo. $O$ trabalho ainda é a principal, se não única, forma de inserção nessa sociedade - digase, de forma cada vez mais degradada. Migração e trabalho permanecem possuindo uma imbricação fundamental, cujo significado vai além da constatação mais superficial do fato da migração. Estudar os meandros desta realidade cambiante da mobilidade humana na hora atual do desenvolvimento do capitalismo em sua relação com o mundo do trabalho, em toda a sua complexidade $e$ conseqüências, é uma tarefa de primeira ordem que ainda precisa ser empreendida.

\section{Sidnei Marea Darnelas}

